\title{
Use of geothermal energy and mineral waters in Bulgaria: current status and perspectives
}

\author{
Vladimir Hristov ${ }^{l}$
}

${ }^{1}$ Geological Institute, Bulgarian Academy of Sciences, 1113 Sofia, Bulgaria;

e-mail: vhh@geology.bas.bg

\section{Използване на геотермална енергия и минералните води в България: състояние и перспективи}

\author{
Владимир Христов
}

Hristov, V. 2020. Use of geothermal energy and mineral waters in Bulgaria: current status and perspectives. Engineering Geology and Hydrogeology, 34, 7-17.

\begin{abstract}
Summary data on the geological survey, hydrogeological and hydrochemical conditions, as well as on the use of geothermal energy and mineral waters during different periods in Bulgaria are presented. One of the aims of the paper is to present some problems concerning more rational and full application of the available geothermal resources, as well as the management of the existing geothermal resources to protect mineral water from contamination. Some examples are given from other countries (Austria, Russia) with similar hydrogeological conditions in the respective sites, which have smaller hydrothermal resources but use them more fully in the presented cases. Finally, brief information is provided on a new environmental technology for the use of geothermal energy, developed by the Canadian company "Eavor". This technology could be applied in the near future in a number of areas in Central North and Northwestern Bulgaria where geological conditions are similar.
\end{abstract}

Keywords: groundwater, mineral waters, geothermal resources, geothermic.

Резюме. Представени са обобщени данни за геоложкото проучване, хидрогеоложките и хидрохимични условия, както и за използването на геотермална енергия и минерални води през различни периоди в България. Една от целите на статията е да представи проблеми за разрешаване, свързани с по-рационалното и пълно приложение на наличните геотермални ресурси, както и стопанисването на съществуващите водовземни съоръжения за опазване на минералните води от замърсяване. Дадени са примери от други държави (Австрия, Русия) със сходни хидрогеоложки условия в съответните находища, които разполагат с по-малки хидротермални ресурси, но ги използват по-пълноценно в представените случаи. Накрая е дадена кратка информация за нова екологична технология за използване на геотермалната енергия, разработена от канадската фирма «Eavor», която в близко бъдеща би могла да се прилага в редица площи в Централна Северна и Северозападна България, където геоложките условия позволяват внедряването ѝ.

Ключови думи: подземни води, минерални води, геотермални ресурси, геотермия. 


\section{Въведение}

Изследванията и използването на минералните води и геотермалната енергия са актуални и значими за България, която по богатство на наличните ресурси се нарежда на едно от челните места в Европа след Исландия, Италия и Турция. Понастоящем в страната ни съществуват около 630 геотермални източници (естествени извори, каптажи и сондажи), които са съсредоточени в около 170 геотермални находища и 90 водопроявления. Естествените минерални извори се използват още от древността, като през последните десетилетия са създадени традиции в прилагането им за балнеоложки и профилактични цели, възстановяване и спорт (плувни басейни), отопление на сгради, оранжерии и пр. След 1990 г. все по-често термалните (минералните) води у нас се използват в спа-хотели и балнеоложки центрове към тях, както и във фабрики за бутилиране на натурална минерална вода, като броят на бутилиращите предприятия е нараснал от три (1990 г.) на повече от четиридесет през последните 30 години.

\section{Минерални води в България}

Традиционното използване на минералните (термалните) води в България условно може да се раздели на три основни периода. Пьрвият обхваща повече от 2000 години (до около 1960 г.), а следващите два са много по-кратки - всеки от тях е с продължителност около 30 години (съответно от 1960-1990 г. и от 1990 досега).

Използването на минералните води по нашите земи през първия период, започнал от древността, когато редица тракийски селища възникват около естествени минерални извори, какъвто е случая и със Сердика, сегашната столица София. По-късно по време на управлението на Римската империя по нашите земи (46-395 г. сл. Хр.) в многобройни селища са построени римски обществени бани с минерални води, чиито руини са останали до наши дни (София, Кюстендил, Сапарева баня, Хисаря и др.). Тази традиция за използване на минерални води е продължена и по време на турското управление на сегашната българска територия. За това свидетелстват руините на турски бани в София, Пловдив и много други градове, както и някои досега действащи турски бани - с. Баня, Разложко и др. Едва в края на първия период (втората половина на XIX и началото на XX век) започва геоложкото проучване, хидрохимичното изследване за лечебните свойства и качествения състав на минералните води у нас. По същото време излизат първите публикации и монографии, отнасящи се до това природно богатство на страната ни, като най-важното обобщение за хидрохимичните данни е представено в монографичен труд (Azmanov, 1940). През 1950-те години първите випускници завършват специалност хидрогеология и някои от тях започват да полагат основите на хидрогеоложките проучвания в страната, включително и в термоминералните находища. В края на първия период излиза още една монография (Kusitaseva, Melamed, 1958), посветена на изследване на химическия състав на минералните води в страната.

Вторият период (1960-1990г.), който може да се нарече «златен» за развитието на хидрогеоложките проучвания и използването на термоминералните води, започва още в началото си с интензивно сондиране, включително и в находищата на минерални води с цел прекаптиране на съществуващите естествени минерални извори и увеличаване на количеството и температурата им. Многобройни са организациите, които взимат участие в хидрогеоложките проучвания и сондажната дейност в съществуващите находища. Открити са нови термоминерални находища (Девин, Белица, Кромидово, Казичене-Равно поле и др.), които не са имали естествени водопроявления на повърхността. През втория период излизат две монографии, посветени на минералните води 
в страната (Shterev, 1964; Petrov et al., 1970), които обобщават всички резултати от хидрогеоложките проучвания, проведени от геоложките проучвателни предприятия в страната. Според Shterev (1964) находищата на минерална вода в страната са около 230, a Petrov et al. (1970) считат, че те са около 170 и определят останалите като отделни водопроявления. През този период са публикувани десетки статии и доклади, които е трудно да се изброят, за хидрогеоложките условия, охранителните зони и качествата на минералните води. Интензивните сондажни, геофизични и хидрохимични проучвания и анализи на минералните води подготвят следващия трети период, когато натрупаният фактически материал започва да се обобщава в различни монографии.

Последният (трети) период започва от 1990 г., продължава и понастоящем и се характеризира с драстично намаляване на сондажните проучвания, съкращаване на състава в геолого-проучвателните предприятия, закриване на част от тях (Дирекция хидрогеоложки и инженерногеоложки проучвания към ЕНЕРГОПРОЕКТ, ВОДПРОЕКТ и др.) и е свързан с финансови трудности и съкращаване на геоложките проучвания. Независимо от обективните трудности, съпътстващи и хидрогеоложките проучвания и хидрохимични изследвания на хидротермалните находища, през този период също са публикувани значими трудове за минералните води и геотермалната енергия - в областта на хидрохимията Pentcheva et al. (1997), Vladeva et al. (2000), геофизиката Bojadgieva \& Gasharov (2001), хидрогеологията - Galabov \& Stoyanov (2011), Penchev \& Velichkov (2011) и др.

На територията на България са разпространени скали с различен произход и литоложки състав, с възраст обхващаща почти целия спектър от Прекамбрия до Кватернера. Разграничават се две коренно различни обширни зони - Южна и Северна България, разделени от Стара планина, предопределящи различни условия за формиране и акумулиране на минералните води (Shterev, 1964; Petrov et al., 1970; Benderev et al., 2016 и др.). Южна България изцяло се отнася към Алпийския ороген и се характеризира със сложен тектонски строеж, с нагънати структури, наложени грабеновидни депресии, запълнени с кватернерни и плиоценски наслаги, съдържащи порови минерални води, акумулирани в подълбоки водоносни хоризонти. Разломните нарушения предопределят наличието на пукнатинни водонапорни системи. Преобладаващо значение за тази част от страната имат пукнатинните и карстови води с активна циркулация и в повечето от случаите с напорен характер.

Северна България е изцяло разположена върху част от Мизийската платформа, което е предпоставка за оформянето на голяма артезианска структура, с етажно разположени водоносни хоризонти и водоупори, затъващи главно в северна посока. Различните геолого-структурни и хидрогеоложки условия оказват значение и върху разпределението на топлинното поле в страната - важен фактор за формирането на термалните и минерални води. Съгласното (Velinov, Bojadgieva, 1981; Khutorskoy et al., 2019) с висока степен на увереност може да се предполага повишаване на температурата на една и съща дълбочина от север на юг в Южна България, а в рамките на Мизийската платформа - от запад на изток.

В Северна България термалните водоносни хоризонти се разкриват с редица сондажи, които са прокарвани главно с цел търсене на нефт и газ. Дълбочината им е от няколко стотин до повече от $6000 \mathrm{~m}$. Температурата на водите зависи от дълбочината на пресичане на съответния водоносен хоризонт, като в найдълбоките им части достига над $100^{\circ} \mathrm{C}$ (Bojadgieva, Gasharov, 2001). Данните от химичния анализ на водоносни хоризонти в Северна България са публикувани от Monahova $(1964,1972,1975)$ и др. Стойностите на общата минерализация варират от по-малко от $1,0 \mathrm{~g} / \mathrm{L}$ в по-плитките части на водоносните хоризонти и Предбалкана до над 150,0 g/L (разсоли) в дълбоките им части. Успоредно с 
увеличаването на общата минерализация се променя типа на водите - от $\mathrm{HCO}_{3}$ $\mathrm{Ca}$ и $\mathrm{HCO}_{3}-\mathrm{Ca}-\mathrm{Mg}$ в $\mathrm{Cl}-\mathrm{Na}$.

В Южна България термалните води са привързани към пукнатинно-разломни водонапорни системи. Дренирането им най-често се осъществява от естествени извори, но през XX-ти век са прокарани редица сондажи в районите около изворите и в зони на предполагаемо неразкрити на повърхността термални води. Дълбочините на сондажите са значително по-малки (в повечето случай до 500$600 \mathrm{~m}$ ) отколкото в Северна България, само в отделни случаи достигат до 2000 m (например край гр. Китен). Химичният състав на подземните води в Южна България е значително по-различен от този в Северна България. Повече от 90\% от водоизточниците имат ниска обща минерализация (под $1,0 \mathrm{~g} / \mathrm{L}$ ). Само за няколко водоизточници, разположени близо до Черноморското крайбрежие (курорт Слънчев бряг), са установени стойности на обща минерализация над $14,0 \mathrm{~g} / \mathrm{L}$. По-голямата част от термалните води в Южна България са азотни, алкални (рН до 10), флуоридни, често радиоактивни. В тях винаги присъства натрий, бедни са на магнезий, предимно $\mathrm{HCO}_{3}-\mathrm{Na} ; \mathrm{HCO}_{3}-\mathrm{SO}_{4}-\mathrm{Na}$ и $\mathrm{SO}_{4}-\mathrm{Na}$ тип. Водите са богати на разтворен и спонтанен хелий и имат специфичен микросъстав - Li, Rb, Cs, W, Ge, Ga, Мо и Be (Pentcheva et al., 1997).

\section{Ресурси и приложение}

В периода 1994-1998 г. се проведоха хидрогеоложки проучвания на всички термоминерални водоизточници в страната под ръководството на Петьр Петров и Илия Йотов (Геологически институт - БАН). Този проект с акроним «ГЕОТЕРМ» е финансиран от Министерството на околната среда и водите (МОСВ). Ръководителите на проекта са мобилизирали почти всички специалисти (около 40 души), които са участвали в проучването и експлоатацията на съществуващите термоминерални водоизточници в страната. По време на проекта са обследвани всички находища и водопроявления, проведени са актуални проучвания във всяко едно от тях, като са определени ресурсите. В рамките на този проект е създадена база от данни, която включва около 2000 паспорта на сондажни водоизточници и около 1000 - на естествени минерални извори, съхранявана в МОСВ. Съставени са повече от 30 доклада и обобщителен през 1998 г. Това е наймащабното проучване на минералните води у нас до днес. Резултатите от него са се превърнали в основа на следващите локални проучвания на термоминералните находища в страната. Необходимо е след изминалия 22-годишен период да се стартира нов подобен проект, който да представи актуална картина на ситуацията в страната понастоящем. Някои обобщени данни от проекта «ГЕОТЕРМ» са следните (Петров и др., 19981):

Ресурсите на термалните води са около $4600 \mathrm{~L} / \mathrm{s}$, като топлинната енергия възлиза на $315 \mathrm{MWt}$, в които стойности не са включени дълбоките води от артезианските водоносни хоризонти в Северна България. Като цяло експлоатацията на термалните води е насочена към водоизточниците в Южна България и към ниско минерализираните термални води в артезианските басейн в Северна България, главно Варненския артезиански басейн. Засега почти отсъства интерес към водите с по-високи температури в дълбоките части на водоносните хоризонти с много висока обща минерализация (до 150 g/L).

Приложението на минералните води все още е 25-30\% от общия ресурс. Естествените термални извори и термална вода, открити в стотици сондажи в страната, имат само пряко приложение поради сравнително ниската им температура.

'Петров, П. и др. 1998. Преоценка на хидротермалните ресурси в България. Отчет по програма ГЕОТЕРМ на МОСВ (Геофонд МОСВ). 
Традиционно по-голямата част от минералните води се използват за балнеология - около 60\% (включително минерални бани, лечебни и спортни басейни), до $23 \%$ за други цели и $17 \%$ за директно водоснабдяване, оранжерийно топлоснабдяване, както и за бутилиране на натурална минерална вода. Поради сравнително ниската температура на термоминералните води няма производство на геотермална електроенергия в страната.

През последните около 30 години непрекъснато нараства броя на откритите и закрити минерални басейни, като са построени десетки нови в 44 селища в страната, дори в населени места с малък брой жители като с. Спанчевци и с. Баня (Разложко).

Бутилирането на натурална минерална, изворна и трапезна вода също бележи голям напредък от 1990 година досега, като е нараснало от 3 до повече от 40 нови предприятия, разположени в Южна България, където минералните водоизточници са в непосредствена близост, а планинските извори (използвани за бутилиране на изворна вода) отстоят максимум на разстояние до $12 \mathrm{~km}$ от бутилиращите фабрики.

\section{Проблеми с опазването на водоизточниците и минералната вода}

Винаги са съществували проблеми с опазването на водоизточниците на минерална вода, но те особено се увеличиха през третия от представените погоре периоди - след 1990 г. Основните проблеми за находищата и използването на минералните води в страната са остарелите водовземни съоръжения, които са преминали отдавна експлоатационния си период; лошото стопанисване на каптажните съоръжения, заниженият контрол при ползването и опазването на минералната вода и др. Могат да бъдат посочени десетки примери за лошото състояние на водоизточниците и съпътстващите ги съоръжения, но ще бъдат посочени само един-два, защото проблемите са сходни.

В началото на 1980-те бе открита най-горещата вода в Софийската котловина чрез сондаж Р-1хг (с. Казичене, Софийско) - с първоначална температура $81^{\circ} \mathrm{C}$. По същото време в района на Казичане-Равно поле са изградени повече от 150 сондажа, от които повече от 30 са достигнали мезозойската подложка на котловината и в продължение на години са използвани, а някои се ползват и понастоящем. Така е разкрито ново находище (Казичене-Равно поле) на минерални води без да е имало в района естествени минерални извори. След приключването на сондажните работи е построен водопровод с дължани около $3 \mathrm{~km}$ до с. Кривина за водоснабдяване на парници край селището. Около 10 години по-късно изолацията на тръбите е разграбена. Малко по-късно целият водопровод е демонтиран и вероятно е предаден за скрап. Металната врата, помпата, електрическото табло и останалата апаратура в каптажа са изчезнали. Сега съоръжението (сондаж Р-1хг) прилича на сметище (сн. 1, 2018 г.). Не е много по-различно състоянието и на друг високотемпературен водоизточник $\left(75^{\circ} \mathrm{C}\right)$ в местността Рупите (Кожух) - сн. 2 (2019 г.).

На някои други места каптажите са в по-добро състояние, но водата не се оползотворява и се изхвърля неизползвана, какъвто е случаят с находище Панчарево (каптаж Галерията - сн. 3, 2019 г.), Елешница (Св. Варвара - сн. 4, 2018 г.) и на много други места.

Подобна е картината и в Северна България, където водите са със значителна температура и висока минерализация, но са подходящи за изграждането на геотермални централи за отопление. Например, в геотермална централа Горни Дъбник, предназначена за отопление на административни сгради, е оборудван за целта черпателен сондаж Р-46 и нагнетателен сондаж Р-59 с температура на черпената вода $87^{\circ} \mathrm{C}$ и обща минерализация 20 g/L. През 1997 г., когато е 

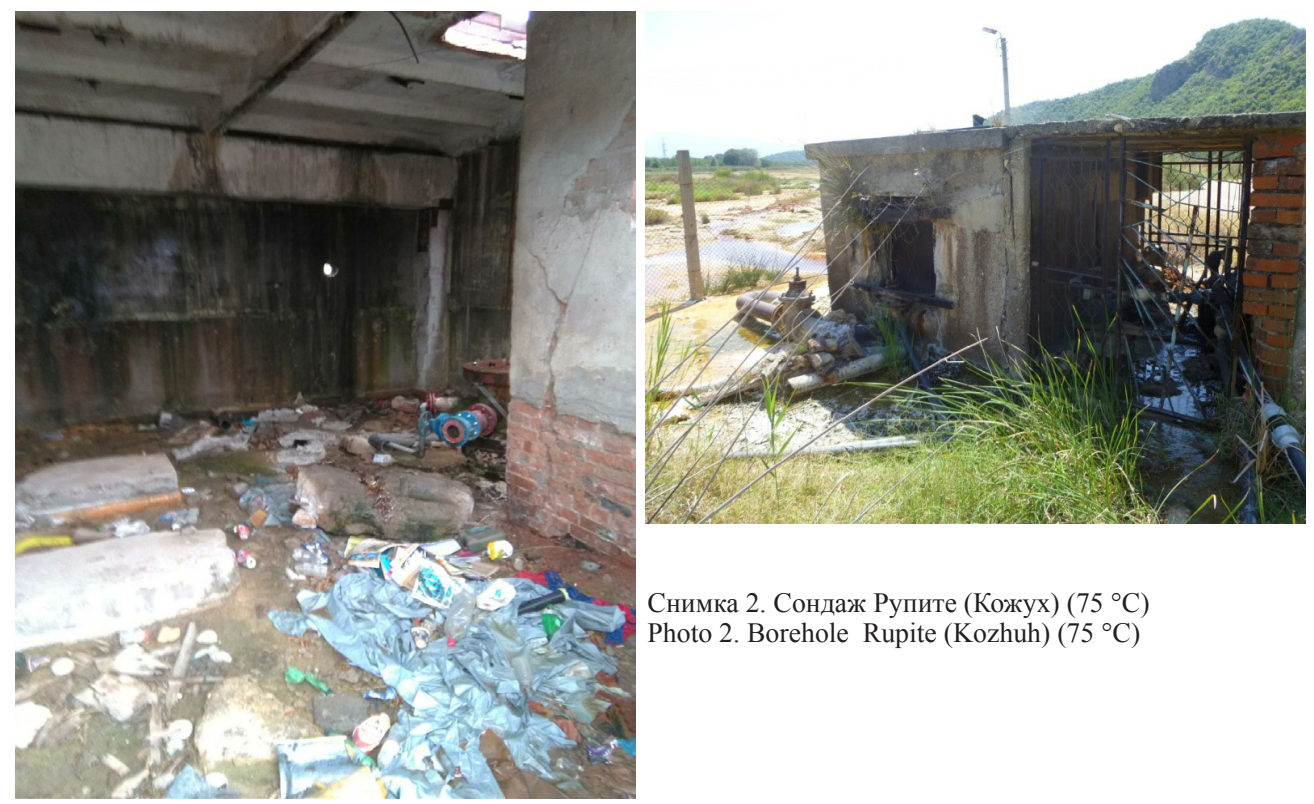

Снимка 2. Сондаж Рупите (Кожух) $\left(75^{\circ} \mathrm{C}\right)$

Photo 2. Borehole Rupite (Kozhuh) $\left(75^{\circ} \mathrm{C}\right)$

Снимка 1. Сондаж Р-1хг Казичене $\left(81^{\circ} \mathrm{C}\right)$

Photo 1. Borehole P-1hg Kazichene $\left(81^{\circ} \mathrm{C}\right)$

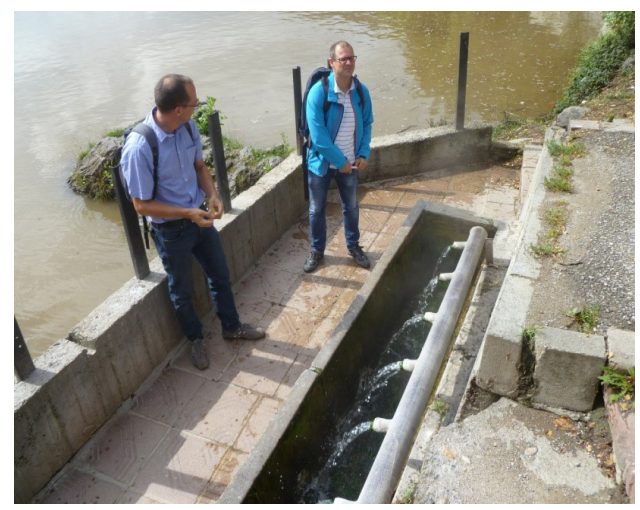

Снимка 3. Панчарево, каптаж Галерията $\left(49^{\circ} \mathrm{C}\right)$ Photo 3. Pancharevo, spring the Gallery $\left(49^{\circ} \mathrm{C}\right)$

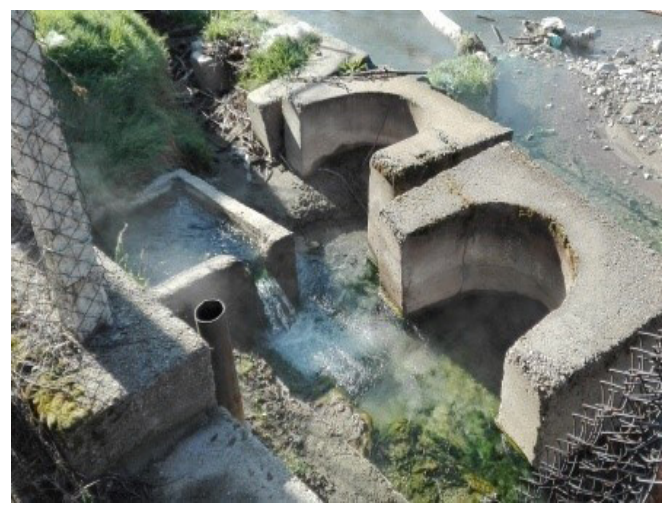

Снимка 4. Елешница (Св. Варвара) $\left(52^{\circ} \mathrm{C}\right)$ Photo 4. Eleshnitsa (St. Varvara) $\left(52^{\circ} \mathrm{C}\right)$

извършено обследване на района, вече нищо не е функционирало в тази централа, както и геотермална централа Долни Луковит, предназначена за отопление на оранжерии.

За всеки един изследовател е ясно, че е необходимо да се предприемат спешни мерки за подобряване състоянието на водоизточниците и минимализиране на неизползваната минерална вода.

\section{Някои примери за използване на термоминерална вода и геотермална енергия в други страни}

Целта на представените по-долу примери е да покажат рационалното използване на термоминерални води и геотермална енергия в страни със сходни хидрогеоложки условия на някои райони в България. 
Пьрвият пример е за сравнително малка геотермална централа в Bearboum an der Safen в Щирия (Австрия) пусната в действие през 2016 г. (Goldbrunner, Goetzl, 2019). За използване на геотермалната енергия са прокарани два сондажа (водочерпателен и реинжекционен), всеки с дълбочина $3200 \mathrm{~m}$, разкриващи малм-валанжинския водоносен хоризонт, представен от варовици (сн. 5 и 6 от 2019 г.). От водочерпателния сондаж чрез високотемпературна потопяема помпа се добива геотермална вода с температура приблизително $125^{\circ} \mathrm{C}$ и дебит около $60 \mathrm{~L} / \mathrm{s}$ (най-високата температура досега от всички геотермални сондажи в Австрия). Водата е $\mathrm{Cl}-\mathrm{Na}$ по тип с обща минерализация, възлизаща на $78 \mathrm{~g} / \mathrm{L}$. Реинжекционният сондаж е разположен на около $1800 \mathrm{~m}$ от водочерпателния (експлоатационния) и в близост до него са разположени топлообменниците. Инсталираната в момента топлинна мощност е $15 \mathrm{MWt}$, която се използва за отопление на оранжерии и административните сгради към тях. Върху част от топлообменниците се отлага $\mathrm{NaCl}$ (сн. 7), който периодично се премахва. Служителите са около 200 души, повечето от близките селища (сн. 8).

Този пример с оранжерии в Австрия може да се използва в България, главно в Централните и Западните части на Северна България, където има условия за наличие на води с температура над $100^{\circ} \mathrm{C}$, макар и с твърде висока обща минерализация. Тази възможност е доказана в миналото с изградените в края на 1980-те години геотермални централи в Долни Дъбник и Долни Луковит.

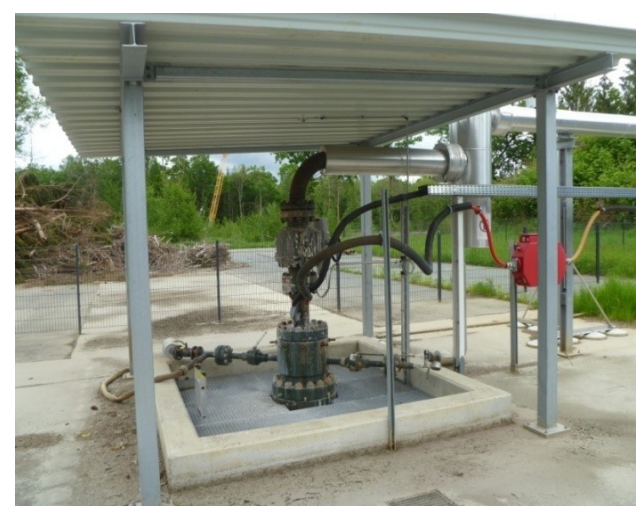

Снимка 5. Водочерпателен сондаж $(3200 \mathrm{~m}), 125^{\circ} \mathrm{C}$ Photo 5. Pumping Borehole $(3200 \mathrm{~m}), 125^{\circ} \mathrm{C}$

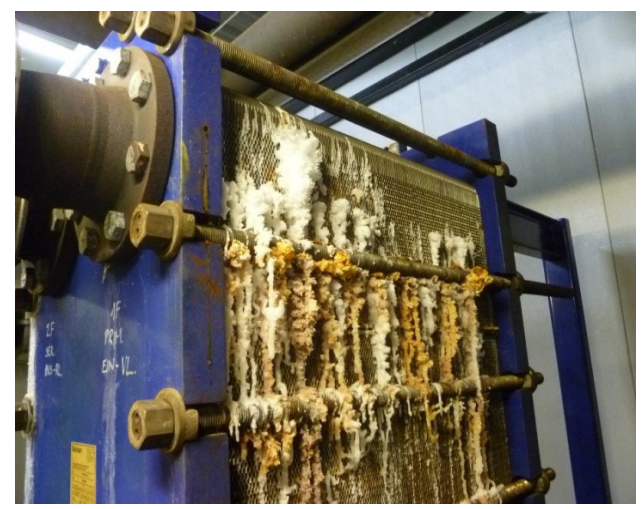

Снимка 7. Топлообменници с отложения от $\mathrm{NaCl}$ Photo 7. Heat exchanger with $\mathrm{NaCl}$ deposits

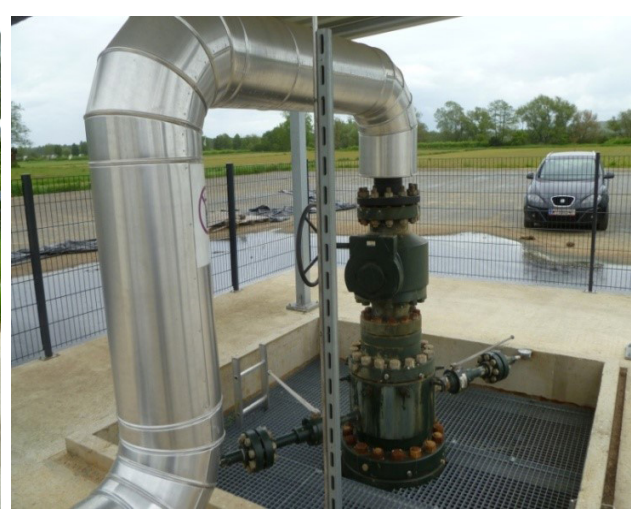

Снимка 6. Реинжекционен сондаж (3200 m), 60 L/s Photo 6. Re-injection Borehole $(3200 \mathrm{~m}), 60 \mathrm{~L} / \mathrm{s}$

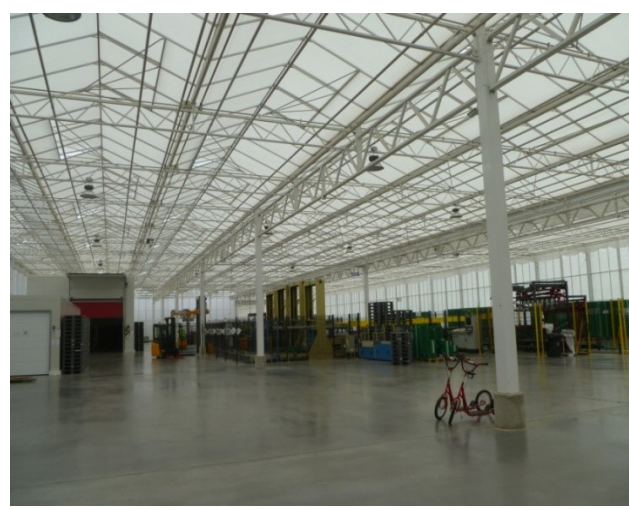

Снимка 8. Оранжерии 250 декара, 200 служители Photo 8. Greenhouses 250 da, 200 employees 
Вторият пример е свързан с пет световно известни руски находища на минерални води (Кисловодск, Пятигорск, Железноводск, Есентуки и Нагутск), разположени северно от Кавказ. Развитието на някои от тях започва преди повече от 300 години (по времето на цар Петьр Велики). Техният химически състав (Таблица 1) показва, че това са минерализирани води - от 1,3 до 13,7 g/L, които могат да се използват за пиене само в ограничени количества, препоръчително по лекарско предписание. Температурата им е съпоставима с тази на повечето минерални води в България и варира в петте находища в диапазона $13-60^{\circ} \mathrm{C}$. Експлоатационните ресурси на тези находища възлизат общо на приблизително $90 \mathrm{~L} / \mathrm{s}$, а количеството на използваните минерални води много наподобява характерното за България - 23-34\% от общото (Таблица 2). Голямата разлика с българските курорти е в многобройните санаториуми в тези находища, които възлизат на 86 бр. Ако сравним тези пет световно известни находища с

Таблица 1. Химически състав на минералните води в руски находища (Potapov et al., 2019) и Велинград (Vladeva et al., 2000)

Table 1. Chemical composition of mineral waters in Russian deposits (Potapov et al., 2019) and Velingrad (Vladeva et al., 2000)

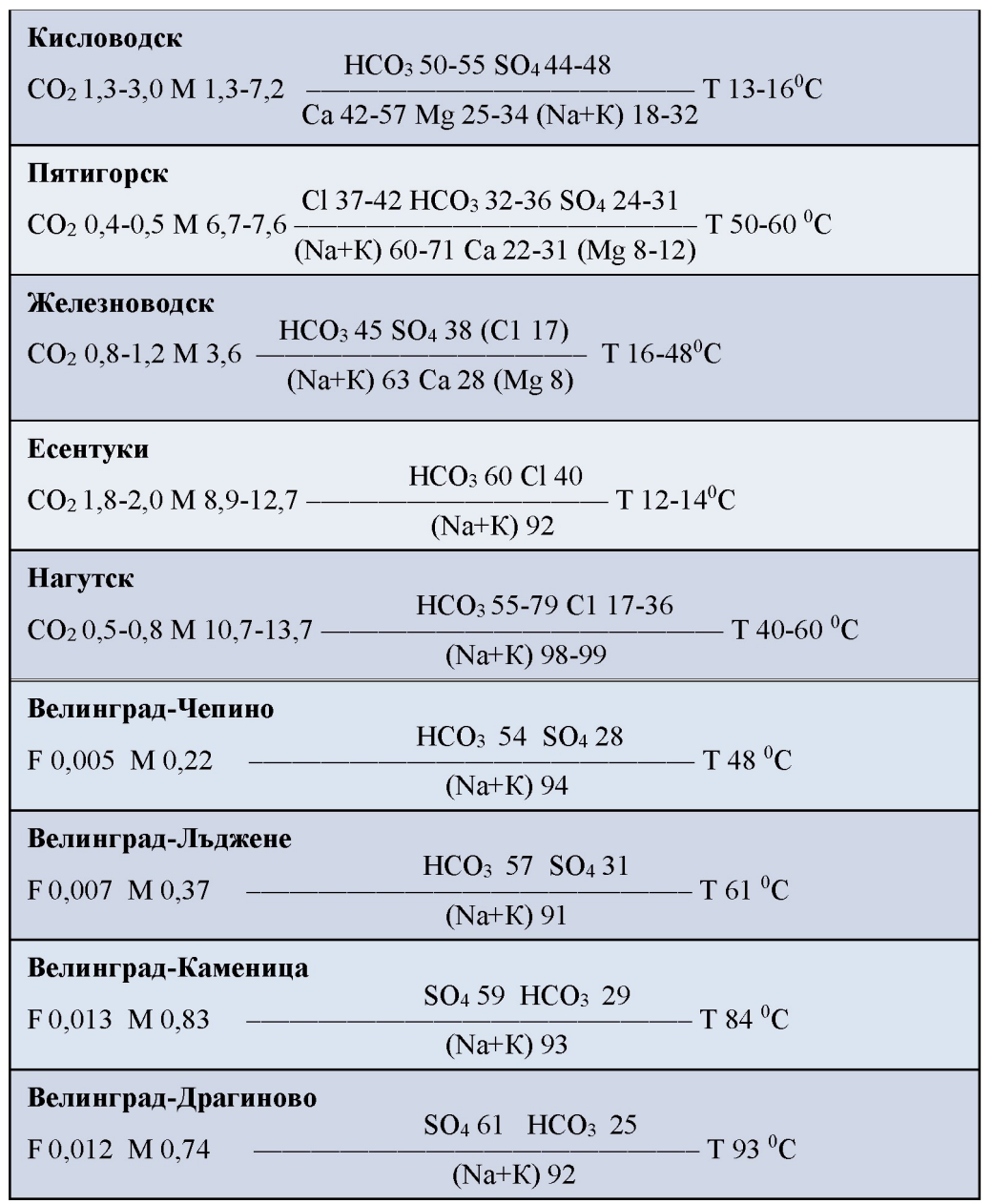


четирите български (Чепино, Льджене, Власа и Драгиново), разположени на територията на Велинград, ще стане ясно за големите възможности на нашите курорти. Находищата във Велинград са с общ воден ресурс 132 L/s, температура на минералната вода от 37 до $94^{\circ} \mathrm{C}$ и обща минерализация на всеки от водоизточниците под $1 \mathrm{~g} / \mathrm{L}$, което е предпоставка за успешното бъдещо развитие на този град като един от най-големите балнеоложки центрове на Балканския полуостров. Основният проблем за находищата и използването на минералните води във Велинград е сходен с характерните за страната - остарели водовземни съоръжения, които са преминали отдавна експлоатационния си период; лошо стопанисване на каптажните съоръжения, занижен контрол при ползването и опазването на минералната вода и др. Многобройните спа-хотели в града (повече от 60), повечето от които построени след 1990 г., както и водоналивното предприятие в кв. Чепино показват усилията на местните власти и бизнеса да се усвояват все по-пълноценно водните ресурси, което е предпоставка и за решаване на наболелите проблеми, свързани с опазването на водовземните съоръжения и минералните води в града.

Таблица 2. Ресурси и използване на минералните води (Potapov et al., 2019)

Table 2. Mineral water resources and utilization (Potapov et al., 2019)

\begin{tabular}{|l|l|l|l|}
\hline Курорти & Дебит Q (L/s) & $\begin{array}{l}\text { Използвана } \\
\text { минерална вода (\%) }\end{array}$ & Санаториуми (бр.) \\
\hline Кисловодск & 21,0 & $30-50$ & 38 \\
\hline Есентуки & 11,5 & $30-40$ & 16 \\
\hline Пятигорск & 32,5 & $7-10$ & 17 \\
\hline Железноводск & 21,8 & $30-40$ & 14 \\
\hline Кумагорск & 3,0 & $20-30$ & 1 \\
\hline Общо: & $89,8 \mathrm{~L} / \mathrm{s}$ & $23-34 \%$ & 86 бр. \\
\hline
\end{tabular}

\section{Поглед към бъдещото използване на геотермалната енергия}

Пилотният проект на фирма Eavor, Канада е започнал през юли 2019 г. и на 1 септември 2019 г. безопасно и успешно е осъществено първото в света подземно мултилатерално „скачване“ на хоризонтални сондажни латерали (фиг. 1). Вертикалните сондажи с дълбочина $2000 \mathrm{~m}$, а разстоянието между тях е $2500 \mathrm{~m}$, което много наподобява параметрите на стандартните двойки сондажи (водочерпателен и реинжекционен) за извличане на геотермална енергия.

Революционното в предложената технология от Eavor e, че не се използва вода или прегрята водна пара, не се получават отпадни разсоли или твърди отпадни продукти и няма замърсяване на подземни водоносни системи. Фирмата прилага безвредна работна течност, която циркулира в тръби в затворен цикъл, подобно на огромен подземен радиатор. Този „радиатор“ просто акумулира топлина от естествения геотермален градиент на Земята, използвайки завишените скални температури на дълбочина около $2000 \mathrm{~m}$. За разлика от традиционните геотермални станции, които използват прегрети водни пари до $300^{\circ} \mathrm{C}$ или геотермални подземни води с температура над $150^{\circ} \mathrm{C}$, Eavor не е обременен с проучвателен риск или от търсене на силно пропускливи водоносни хоризонти при високи температури. Новата предлагана система използва само повишената температура на скалите, като работният флуид (течност) няма директен контакт с околната среда. За разлика от вятьрната и сльнчевата енергия, технологията на 


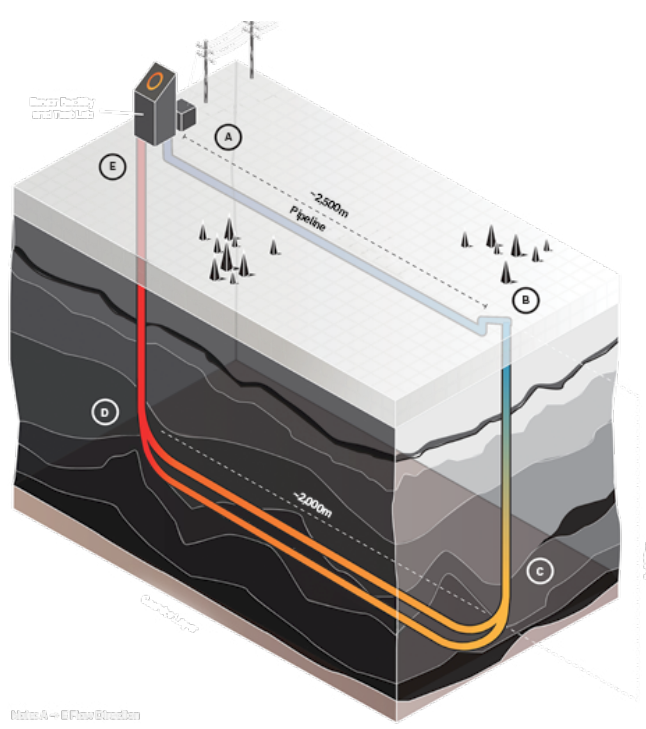

Фиг. 1. Схема на фирма Eavor, Канада за използване на подземната топлина (https://eavor.com/)

Fig. 1. Scheme of Eavor Technologies Inc., Canada for underground heat utilization (https://eavor.com/)

фирмата гарантира непрекъсващ процес на усвояване на енергия и произвежда така необходимата мощност постоянно.

Тази нова екологична технология за усвояване на геотермалната енергия може успешно да бъде прилагана в редица площи в Централна и Западна Северна България, както и на други подходящи места в страната.

\section{Заключение и препорьки}

От представения кратък преглед на състоянието и използването на геотермална енергия и минерални води в страната, както и някои примери от други държави, могат да се направят следните обобщени заключения и препоръки:

- Необходимо е все по-пълно използване неусвоените хидрогеотермални ресурси на България, които възлизат на около 70\% от общите или повече от 200 MWt топлинна мощност;

- Запазване иподобряване състоянието на съществуващите водоизточници, качествата и количествата на минералните води. Прекаптиране на остарели водоизточници;

- $\quad$ MOCВ да инициира преоценка на геотермалните ресурси, като обедини усилията на всички действащи хидрогеолози и други специалисти, свързани с тази тема, т.е. стартиране на ГЕОТЕРМ-2;

- Прилагане на нови технологии, като тази представена от канадската фирма Eavor, за усвояване на геотермална енергия в подходящи площи в страната.

\section{Благодарности}

Настоящото проучване е подкрепено финансово от Руския «Фонд за фундаментални изследвания» (проект № 18-55-18004) и Българския «Фонд за научни изследвания» (проект № 02/63-2018). 


\section{Литература}

\section{References}

Azmanov, A. 1940. Bulgarian mineral springs. State printing, MTPT, Natural resources department, 260 p. (in Bulgarian with a German abstract).

Benderev, A., V. Hristov, K. Bojadgieva, B. Mihailova. 2016. Thermal waters in Bulgaria. In: Mineral and thermal waters of southeastern Europe (ed. P. Papic). Springer, series Environmental Earth Sciences, 47-64.

Bojadgieva, K., S. Gasharov. 2001. Geothermal Catalogue of Bulgaria. GorexPress, Sofia, $168 \mathrm{p}$.

Galabov, M., N. Stoyanov. 2011. Thermo-hydrodynamics of geothermal fields. VanyoNedkov, 140 p. (in Bulgarian).

Goldbrunner, J., G. Goetzl. 2019. Geothermal Energy Use, Country Update for Austria. European Geothermal Congress 2019 Den Haag, The Netherlands, 11-14 June 2019, 6 p., http://europeangeothermalcongress.eu/wp-content/uploads/2019/07/ CUR-01-Austria.pdf

Khutorskoy, M., N. Kostova, A. Benderev, A. Hristov. 2019. Heat Flow and depth temperatures in the Earth crust of Bulgaria based on numerical modeling. Review of the Bulgarian Geological Society, 80, 2, 55-62 (in Bulgarian).

Kusitaseva, V., Y. Melamed. 1958. Composition of Bulgarian mineral waters. J. Medicine and Sports, 280 p. (in Bulgarian).

Monahova, L. 1964. Chemistry and chemical groundwater characterization in oil and natural gas deposits in Northern Bulgaria. GUG, 191-217 (in Bulgarian).

Monahova, L. 1972. I and Br distribution in groundwater in North Bulgarian Artesian Basin. GI, 21, 49-63 (in Bulgarian).

Monahova, L. 1975. Hydrochemical parameters for oil study in Northern Bulgaria. GI, 23, 83-99 (in Bulgarian).

Penchev, P., V. Velichkov. 2011. Hydrothermal fields in Sofia region. Sofia Municipality \& BAPV, 48 p. (in Bulgarian).

Pentcheva, E., L. Van't Dack, E. Veldeman, V. Hristov, R. Gijbels. 1997. Hydrogeochemical characteristics of geothermal systems in South Bulgaria. Universiteit Antwerpen (UIA), Belgium, $121 \mathrm{p}$.

Petrov, P., S. Martinov, K. Limonadov, Y. Straka. 1970. Hydrogeological investigations of mineral waters in Bulgaria. Technika, Sofia, 196 p. (in Bulgarian).

Potapov, E., N. Efimenko, S. Danilov, S. Lyashenko. 2019. The modern state of natural medical resources of the Caucasian Mineral Waters Region. (in print, in Russian).

Shterev, K. 1964. Mineral waters in Bulgaria. Nauka i izkustvo, Sofia, 172 p. (in Bulgarian).

Velinov, T., K. Bojadgieva. 1981. Geothermal investigations in Bulgaria. Technika, 154 p. (in Bulgarian).

Vladeva, L., D. Krasteva, Y. Yordanov, D. Kostadinov. 2000. Reference book for Bulgarian mineral waters. Nauka i tehnika, 225 p. (in Bulgarian). 